172. DIP撮影時におけるAKTON (BOLーX1)の使用経験

立让佼成会附属佼成病院放射線科

\title{
○前澤常晴. 渡辺雅弘
}

\section{(TUNBHARU. MAESAMA) (MASAHIRO.MATAMABE)}

\section{目 的}

現在の放射線を利用する娭查は，P T C D 等に 代表されるように检査自体に長時間在要与るもの が多くなりつつある。ただし，撮影台そのものが X線吸收に対与る配慮から坟時間仰卧する娭查に 不適な什梯で人閫工学的に大きな問题がある。

今问，わ扎扎は，この收善をП的に放射楾治

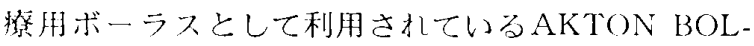

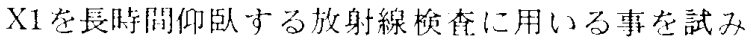
た。その結果，日常隐休に㐫用したとこつ良好な

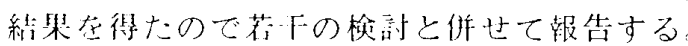

方 法

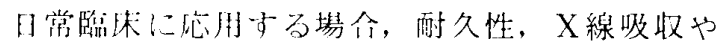

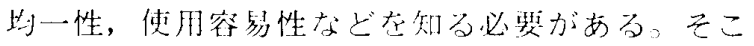

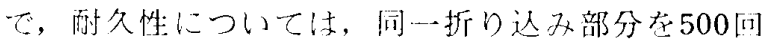
折り这み，1 月间ごとに10kgの加禹在加えたまた， 内部均一性に対しては，C个店用いて調㮅すると ともにC丁值在水奴。来た，X線吸收に間して は, X線つィルんの黑化度から求如た。使用容易 性については，官能梚枯在用いて求めた。

\section{結 果}

耐久性については，方法の項で述べた力法て求 めたが，1[日]目と500[1]日では，その解分のC T 检 枯在行った絬果において変化がないことがわかり ます，また，内部均一性在求めるためにC 影した。このC T 㬐像をphoto I に 示古。CT做毛photoI内に示与が, ほ添水と同様と考えら扎る。军た内 缡構造は均一であることもわかる

$\mathrm{X}$ 線フィルムの黑化度から兒ると AKTON BOL-X1はほぼ体愿と同様 と考えられるので，体厚補洰によって $\mathrm{X}$ 線掫影在行うことが可能であるこ とがわかった。 photo IIIにその! ! 体例 在示少, photo III 向かって左側が, AKTON BOL-X1 在用いた場命，向 かって打側がAKTON BOL-X1 を用 いない場命を示夺が，擬影にはほと 九ど問題がないということがわかる。 AKTON BOL-X1を利用した形を photo II 云与。また，使用容易性 についても官能的には問題がなかっ た。今後さらに，検討を加えて人閒 工学的配慮在考察し, 日常臨床に寄 与したい。

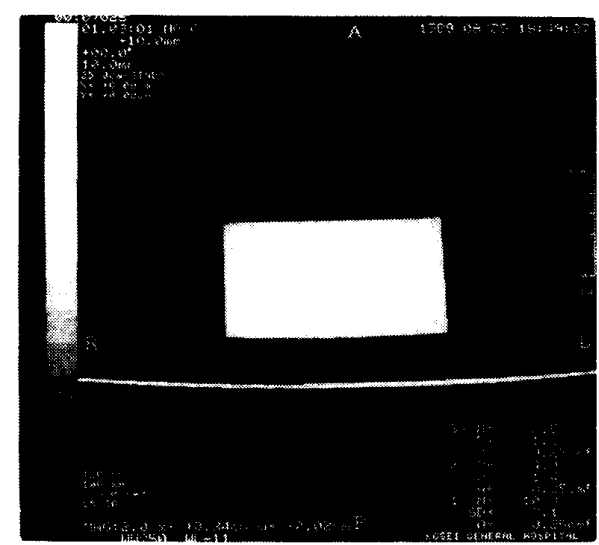

photo I

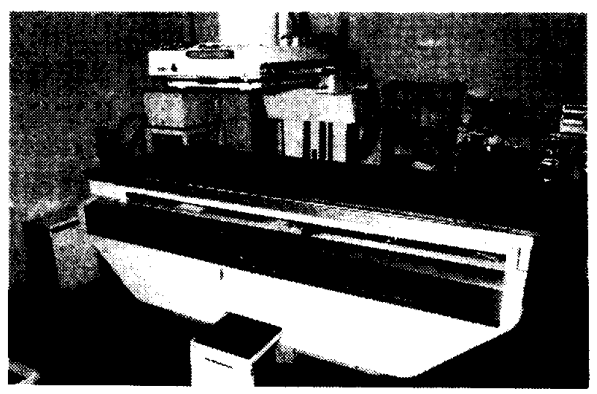

photo II

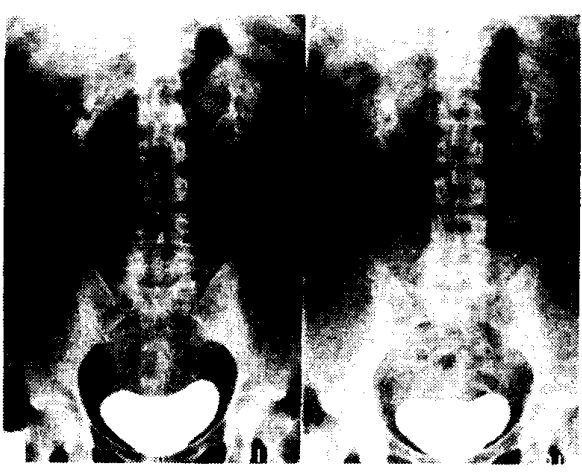

photo III 